\title{
A NOTE ON THE ARTHUR'S PASS EARTHQUAKE 18 JUNE 1994
}

\author{
J.B. Berrill ${ }^{1,2}$, K.J. McManus ${ }^{1,3}$ and G.H. Clarke ${ }^{1}$
}

\begin{abstract}
The M6.3, 18 June 1994 Arthur's Pass earthquake was notable for the strength of shaking recorded at Arthur's Pass Township and for the little damage it caused to bridges and houses. Bridges, the only major man-made structures in the epicentral region except the rail tunnel, survived with only superficial damage, probably because of their dense foundation soils.
\end{abstract}

An accelerogram recorded at the Pass township exceeds the current design motions by about 40 percent in the 0 to 0.5 second band.

\section{INTRODUCTION}

The M6.3 earthquake which occurred at 3:25 pm Saturday June 18,1994 , with an epicentre near Arthur's Pass in the Southern Alps, in the central South Island of New Zealand, caused moderate damage in the township of Arthur's Pass itself and was felt throughout the South Island and as far north as Taranaki in the North Island. The aim of this brief note is to record observations of the response of geologic and man-made structures in the epicentral region two days after the earthquake, and to present an accelerogram of the main shock recorded at Arthur's Pass.

\section{GEOLOGICAL EFFECTS}

Many avalanches occurred in the deep mantle of winter snow on the Craigieburn Range, from Porter Heights west. In general, they seemed to occur on the shaded side of the basin.

Apart from a moderate rockfall in the Lower Otira Gorge, which dammed the Otira River to a height of a few metres, there was no major geologic disturbance visible from the main highway. In the high mountains surrounding Arthur's Pass, the dominant feature of the earthquake effects was the number of large boulders that had fallen. Many of these came to rest on the road; several were two to three cubic metres in volume.

The well-known Zig Zag slide at the head of the Otira Gorge had been little affected. Where fixed markers were present, it appeared that a surface layer of the slide material had moved down-slope about two to three hundred millimetres.

Apart from the large number of boulders that had fallen, the dominant geological feature was the opening of joints in the closely-jointed rock faces exposed in roadway cuts near the railway bridge across the Waimakariri river at Paddy's Bend, east of Bealey Spur, about $15 \mathrm{~km}$ east of Arthur's Pass.

1 Department of Civil Engineering, University of Canterbury, Christchurch, New Zealand

2 (Fellow)

3 (Member)

\section{ROADS}

Minor cracking occurred in the tar-sealed pavement of Highway 73 on fill immediately to the east of Arthur's Pass township where the road sidles down the Bealey Valley, and in the Otira Gorge. Elsewhere, roads seemed to have performed well, and it is probable that in this region, rain tests slopes, embankments and fills more severely than does an earthquake of this size.

\section{BRIDGES}

We inspected most significant bridges from Porter's Pass to Arthur's Pass. No damage of any importance was found that could be attributed to the earthquake.

Freshly scraped paint on the handrail of the 7-span Broad Creek bridge near Bealey Spur indicated that the east abutment had moved towards the stream by about $40 \mathrm{~mm}$. This movement was taken up in the expansion joints between the four east-most spans.

At the Broken River bridge (Figure 1), constructed in 1992, there was minor spalling of the south-most beam at the east abutment, presumable where it had lightly struck the abutment. Grout had spalled away from around the base of the rubber bearing pads at two of four beams at the east abutment (Figure 2) and at the northern pad at the west abutment. The expansion joint at the east abutment appeared to be quite compressed. At the west abutment, the joint had opened by about $10 \mathrm{~mm}$, suggesting that the superstructure had been permanently displaced by that amount to the east. Distortion in the rubber bearing pads at the west abutment is consistent with such movement (Figure 3) as is displacement of the west abutment (Figure 4).

There was no evidence of piers or piles having moved relative to the ground, at this site or any other, by more than one or two millimetres. Perhaps this is not surprising given the dense nature of the angular sand and gravel comprising the stream beds in this mountainous region, where transport and deposition of sediment takes place in an environment of high energy. 


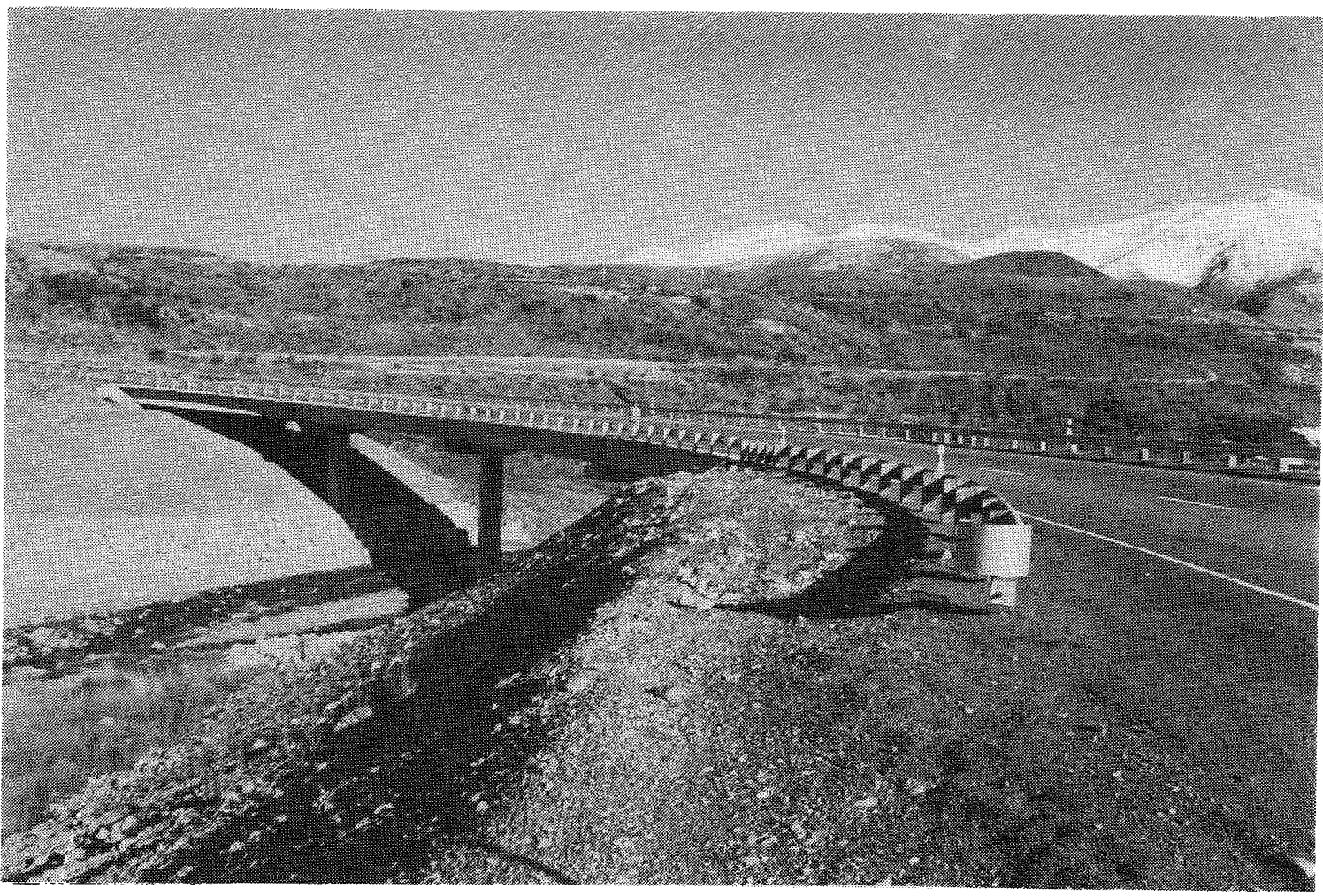

FIGURE 1 Broken River highway bridge looking East

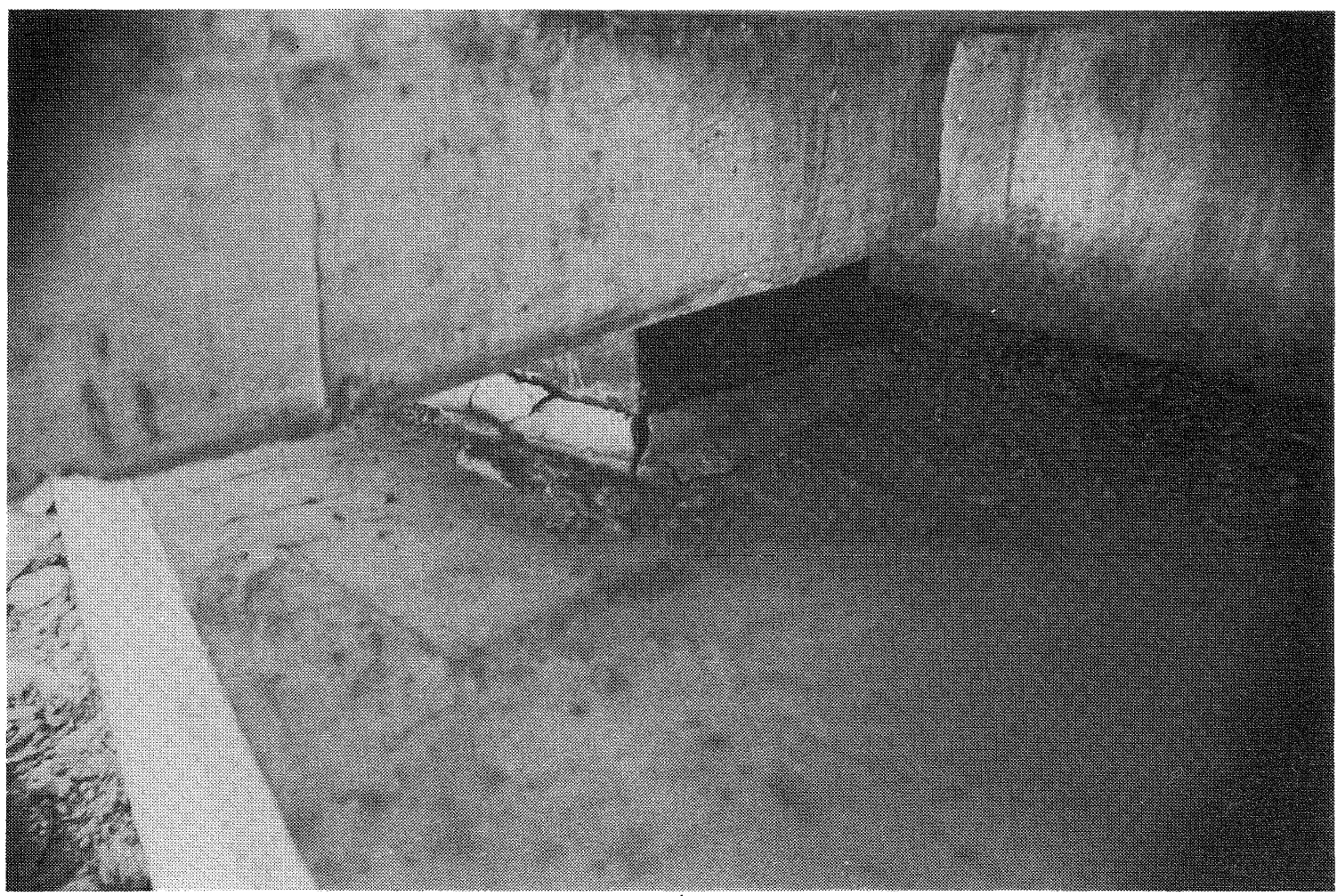

FIGURE 2 Broken River highway bridge, showing inner bearing at eastern abutment 


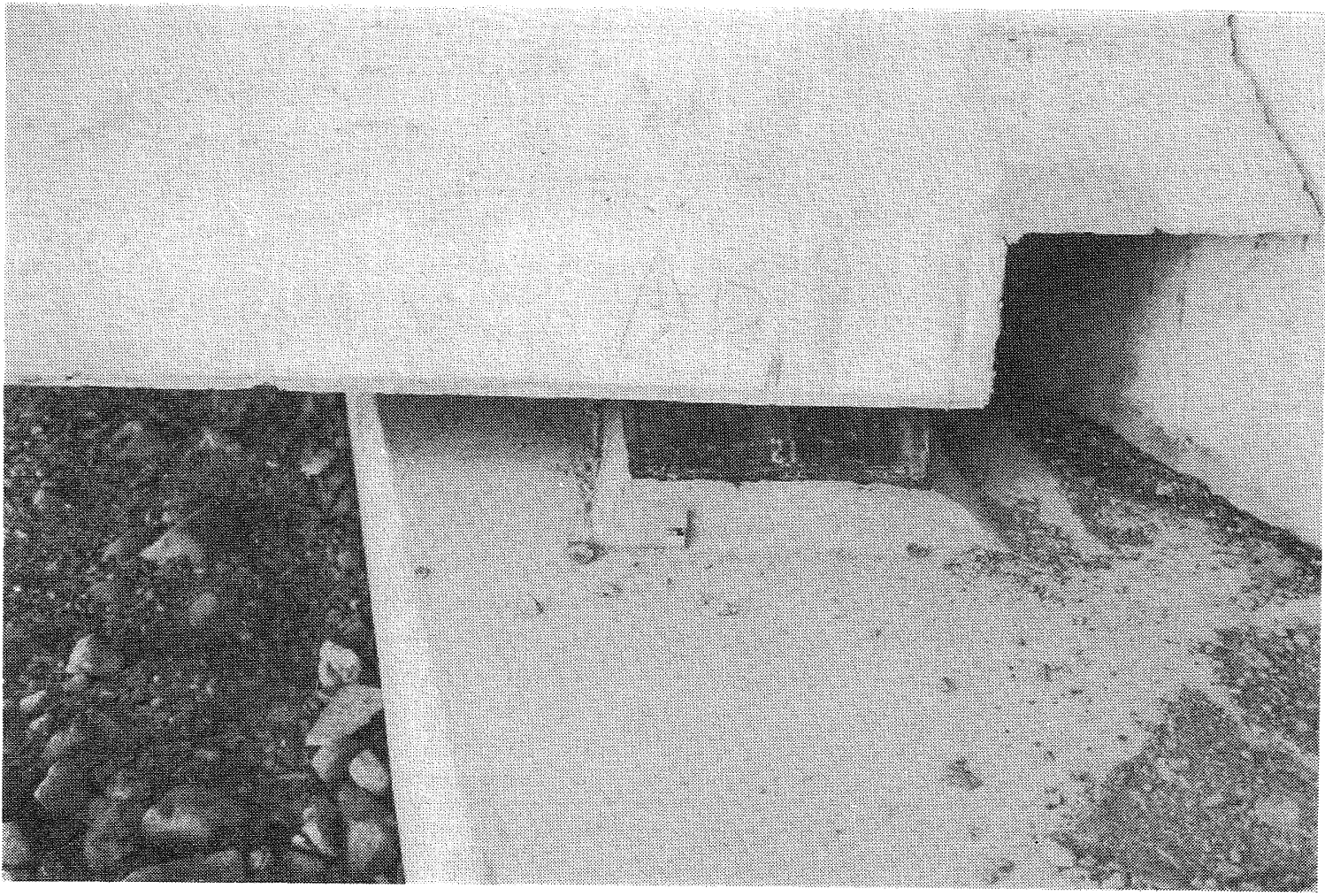

FIGURE 3 Western abutment, Broken River bridge, showing permanent distortion left in rubber bearing

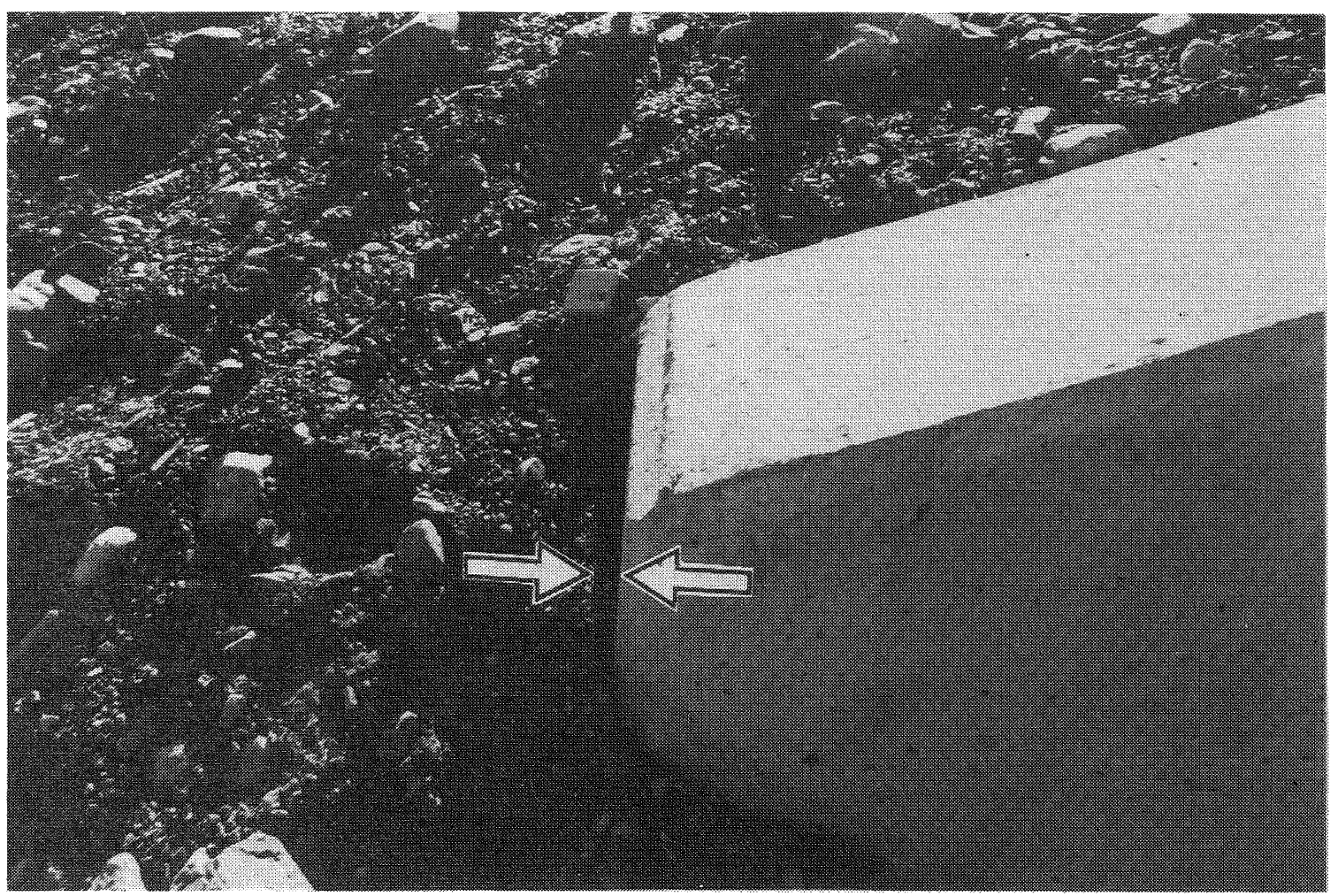

FIGURE 4 Western abutment, Broken River bridge, showing relative movement between ground and abutment 


\section{LIQUEFACTION}

No evidence of liquefaction was found at the bridge sites nor in the many sand bars in the Waimakariri visible from the road. At Lake Sarah, where waterspouts were reported after an earthquake last century, no evidence of ejected sand could be seen; however, we did not search the lake bottom, only the southern shore.

\section{EFFECT ON HOUSES}

At Arthur's Pass township, contents of cupboards and shelves were thrown about; television sets and microwave ovens were particularly vulnerable. But there was little damage to the buildings themselves. At Bealey Spur, the shaking was apparently much less violent, with jars remaining undamaged on narrow shelves. On the other hand, at Castle Hill Village, further from the epicentre, a resident reports that a number of houses, generally with large windows, suffered wracking of their ground-storey walls, with damage to plasterboard linings (presumably, the "design" bracing system).

\section{STRONG MOTION RECORDS}

About 19 accelerograms were obtained: about 17 from instruments operated by the Institute of Geological and Nuclear
Sciences (IGNS), and 2 from instruments owned by the University of Canterbury. In addition, seven records were made on peak-recording scratch-plate (SP) instruments of the IGNS. Records from the University's instrument at Arthur's Pass are reproduced in Figure 5. Peak accelerations from the IGNS instruments are listed in Table 1.

The motions recorded at Arthur's Pass by the University's instrument in the Park Headquarters building, and the IGNS instrument about $300 \mathrm{~m}$ down the valley at the Police Station are amongst the strongest recorded in New Zealand. Response spectra from the horizontal components of the Park Headquarters recording are shown in Figure 6.

The 5 percent damped acceleration response spectra are compared with the current New Zealand design spectrum from NZS4203 for the most severe zone in Figure 7. For this comparison, a structural performance factor of 1.0 was employed. Cross spectra between the June 18th record and previous records from the site have dominant peaks at 0.20 seconds, suggesting a site period of that value, which places the site in the stiff soil or rock category. Hence the rock spectrum values are used. Note that the $\mathrm{N}-\mathrm{S}$ component exceeds the NZS4203 spectrum by 40 to 50 percent over quite a broad band, from 0.08 to 0.5 seconds.
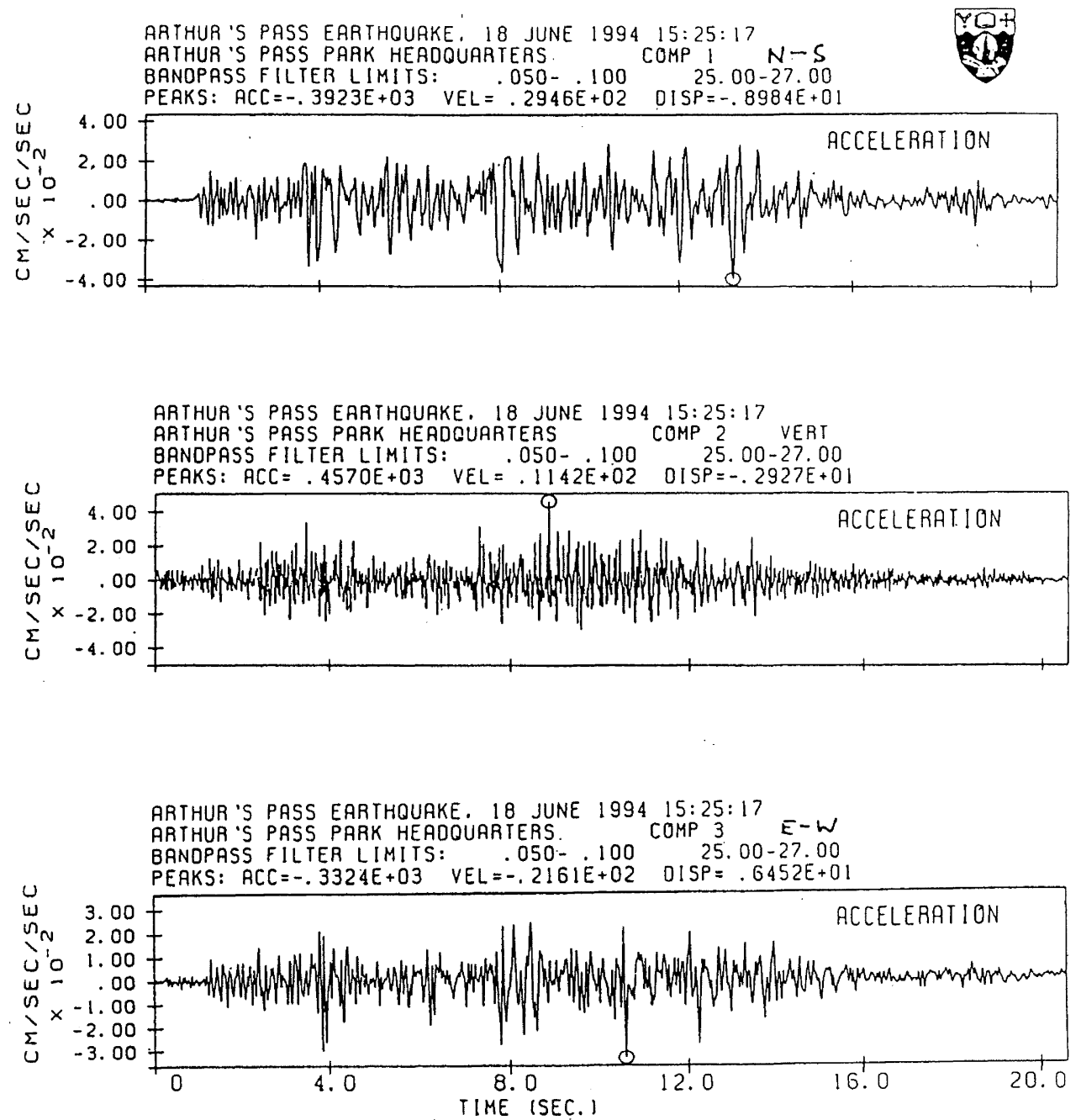

FIGURE 5 Accelerogram from Park Headquarters building, Arthur's Pass 
Table 1 Peak accelerations from 18 June earthquake, from IGNS instruments (G McVerry, pers. comm.)

\begin{tabular}{|l|c|c|c|}
\hline \multicolumn{1}{|c|}{ Site Name } & $\begin{array}{c}\text { Epicentral } \\
\text { Distance } \\
(\mathbf{k m})\end{array}$ & $\begin{array}{c}\text { PGA } \\
\mathbf{( g )}\end{array}$ & $\begin{array}{c}\text { Site } \\
\text { Conditions }\end{array}$ \\
\hline \hline Arthur's Pass Police Station & 13 & 0.489 & $\mathrm{~B}$ \\
Flock Hill Station & 26 & 0.145 & $\mathrm{~B}$ \\
Coleridge Power Station & 37 & 0.135 & $\mathrm{~B}$ \\
Hokitika Medical Centre & 55 & 0.112 & $\mathrm{C}$ \\
Greymouth Telephone Exchange & 69 & 0.048 & $\mathrm{~B} / \mathrm{C}$ \\
Christchurch Canterbury University & 105 & 0.022 & - \\
Reefton Forestry Headquarters & 108 & 0.035 & $\mathrm{~B}$ \\
Christchurch Police Station & 109 & 0.029 & - \\
Christchurch Arts Centre & 109 & 0.020 & $\mathrm{C}$ \\
Hanmer Springs Fire Station & 125 & 0.018 & $\mathrm{C}$ \\
Westport Buller District & 143 & 0.059 & $\mathrm{C}$ \\
Murchison MWD Depot Office & 154 & 0.062 & $\mathrm{C}$ \\
Branch River Power Station & 208 & 0.04 & - \\
Kaikoura Marine Laboratory & 195 & 0.015 & $\mathrm{~A}$ \\
Haast DOC & 217 & 0.019 & $\mathrm{C} / \mathrm{B}$ \\
Nelson Substation & 247 & 0.0073 & - \\
Motueka DOC & 248 & 0.006 & $\mathrm{C}$ \\
Petone, Wellington Newspapers & 347 & 0.003 & $\mathrm{C}$ \\
\hline
\end{tabular}

1 A Rock or very stiff subsoil sites

B Intermediate sites

C Flexible or deep soil sites
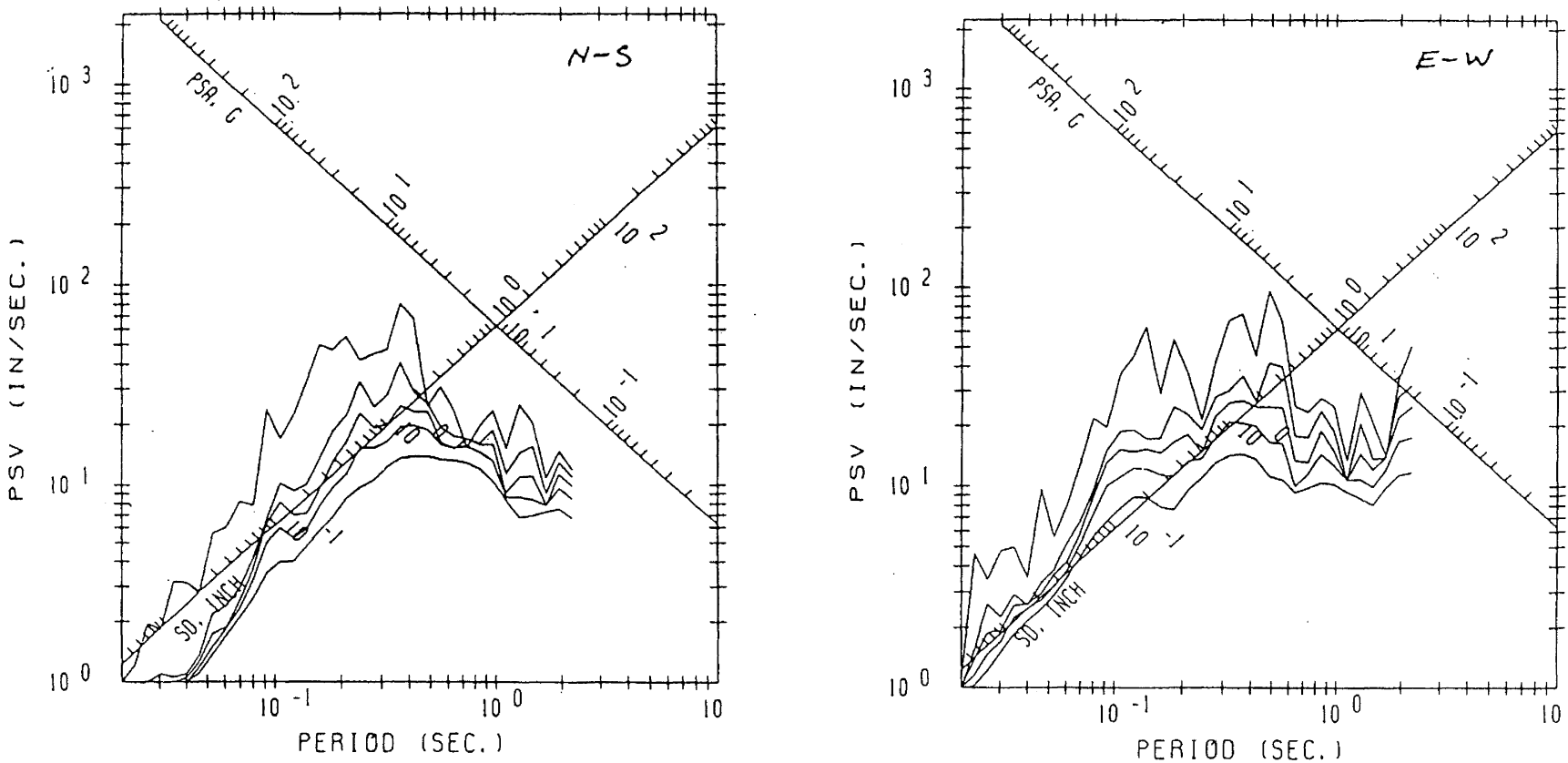

FIGURE 6 Pseudo velocity response spectra for the two horizontal components of motion.

Damping values are 0, 2, 5, 10 and 20 percent 


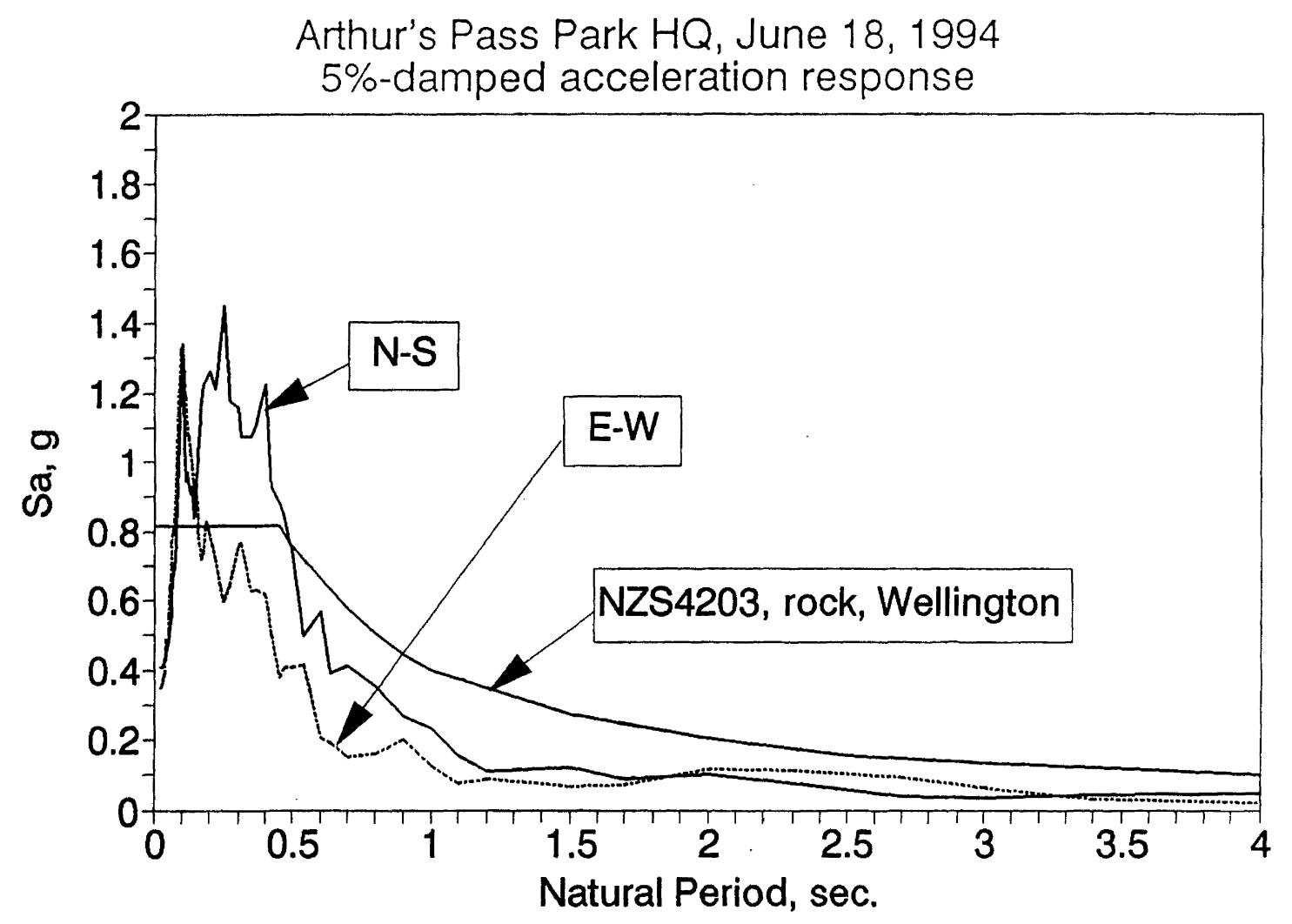

FIGURE 7 Comparison of Arthur's Pass spectra with current NZ code spectrum, for main seismic region (eg, Wellington)

A rough idea of the return period associated with such a record can be obtained by estimating the expected number of earthquakes within a given epicentral distance. Since the epicentral distance of the June 18th earthquake is not known precisely the result is not precise; however, it gives some insight to the hazard. For Smith and Berryman's (1983) source zone D, covering the east coast of the North Island, including Wellington, we obtain the following return periods, as a function of epicentral radius, for an M6.3 earthquake and the range of epicentral distances put forward for the Arthur's Pass earthquake:

Radius, km | Return Period, years

\begin{tabular}{|c|c|}
\hline 10 & 1480 \\
\hline 13 & 875 \\
\hline 15 & 660 \\
\hline
\end{tabular}

Note that the seismicity parameters of Smith and Berryman (1983) used in this calculation represent the average seismicity of the whole zone; some areas close to faults, such as Wellington City, would have smaller return periods than the mean, and others greater. Indeed, since the Wellington Fault is thought to have a characteristic earthquake of a similar strikeslip mechanism, with magnitude 7 to 7.5 and a recurrence interval of about 6 to 700 years (close to the return period intended in the code), our Arthur's Pass record could be regarded as a lower bound to the correct design motions for Wellington.

\section{CONCLUSIONS}

1 The only substantial structures in the epicentral region were bridges. They performed well, almost certainly due to the firm foundation soils found in the high-energy rivers and streams of the area.

2 The marked contrast in damage between the Pass township and Bealey Spur, as well as Castle Hill Village, suggest that shaking strength varied with azimuth as well as distance.

3 Strong shaking was recorded at Arthur's Pass in the earthquake of June 18, 1994, exceeding the NZS4203 motions by about 40 to 50 percent in the 0 to 0.5 second band.

4 The surprising lack of slope failures may be due to the high rainfall of the area, which might put a greater stress on slopes than did this earthquake.

\section{ACKNOWLEDGEMENTS}

The strong-motion accelerographs were purchased with funds from the University Grants Committee and have been maintained with support from the University of Canterbury. $\mathrm{Mr}$ Pierre Normand computed the cross spectra, and Mr Richard Keenan assisted with the processing of the records. Their contributions are gratefully acknowledged.

\section{REFERENCES}

Smith W D and K Berryman. 1983. Revised Estimates of Seismic Hazard in NZ, Bull. NZ Nat. Soc. Earthq Eng, 16(4):259-272. 